\title{
An Assessment of the Impact of International Aid on Basic Education in Ghana
}

\author{
Enoch Nyarkoh ${ }^{1, *}$, Emmanuel Intsiful ${ }^{2}$ \\ ${ }^{1}$ University College of Oslo and Arkerhus, Pb. 4 St Olavs plass, Oslo, Norway \\ ${ }^{2}$ Beijing Normal University, Xinjiekou Wai St., Beijing, P.R China \\ *Corresponding author: enyarkoh08@gmail.com
}

\begin{abstract}
In Ghana and many other developing countries, the substantial investment in and provision of quality education have been identified as the surest path out of persistent poverty. The hope of accelerated development is now hinged on the provision of quality education for it citizenry. However, the inability to raise enough revenue by the government is as a result of varied factors including but not limited to macroeconomic and growth instability, high debt ratios, weak tax administration and large informal (non-taxable) sectors. The intent and desire of the state and government to provide quality accessible education to its citizens and the constraint of inadequate financial resources has compelled Ghana to seek external assistance to fill the resources gaps. Bilateral and multinational donors have responded in diverse ways to the call and over the last two decades, aid increased in quantity and prominence in Ghana's education sector. There are and may be several reasons that could be assigned to the quick response of these bilateral and multinational donors to the call made by Ghana for aid. The paper seeks to comparatively assess the impact international aid has had on Ghana's educational sector over the last two decades in term of access to "quality" education, educational financing and infrastructure expansion at the basic level. This paper argues that, notwithstanding the challenges the educational sector in Ghana is facing, the impact of international stakeholders on educational policy making and practice especially at the basic level has been positive in terms of access, financing and infrastructural expansion.
\end{abstract}

Keywords: International aid, basic education, bilateral/multinational donors, Ghana

Cite This Article: Enoch Nyarkoh, and Emmanuel Intsiful, "An Assessment of the Impact of International Aid on Basic Education in Ghana." American Journal of Educational Research, vol. 6, no. 1 (2018): 43-49. doi: 10.12691/education-6-1-7.

\section{Introduction}

In Africa and many other developing countries, the substantial investment in and provision of quality education have been identified as the surest path out of persistent poverty. As suggested by UNESCO [1], the hope of accelerated development is now hinged on the provision of quality education for it citizenry. However, quality education requires substantial resource investment if the aim is to improve the human capital formation of the country to drive its developmental goals. Provisions of adequate resources by government to the educational sector have always been constrained by the availability of public resources. The inability to raise enough revenue by government is as a result of varied factors including but not limited to macroeconomic and growth instability, high debt ratios, weak tax administration and large informal (non-taxable) sectors. The intent and desire of the state and government to provide quality accessible education to its citizens and the constraint of inadequate financial resources has compelled Ghana to seek external assistance to fill the resources gaps.

Bilateral and multinational donors have responded in diverse ways to the call and over the last two decades, aid increased in quantity and prominence in Ghana's education sector. There are and may be several reasons that could be assigned to the quick response of these bilateral and multinational donors to the call made by Ghana for aid. One obvious reason is opined by Held [2] in Arnove, [3]. He indicated that, the continuous and increased socialization of the world, that is, the linkage of distant localities has the tendency to shape local happenings. Aside other possible motives behind the giving of aid, these international stakeholders responded to this call because the effects of neglect of same would have been obviously negative.

This paper seeks to comparatively assess the impact international aid has had on Ghana's educational sector over the last two decades in term of access to "quality" education, educational financing and infrastructure expansion at the basic level. The paper, for the sake of time and space will focus its comparison from the preindependence period to 1970 and 1980 to 2000. The rationale behind the selection of these periods is that, whilst the educational sector was funded with internally generated resources by the state in the pre-independence to the late 1970s, the early 1980s saw a dramatic change and international influence in the educational sector especially at the basic level with the involvement of international stakeholders when the country adopted the structural adjustment policies. This shift in paradigm was 
largely due to the "universal" acceptance of the attainment of universal basic primary education (UPE) by 2000 at a World Conference on Education for All jointly convened by the World Bank, UNICEF, UNESCO and UNDP, held at Jomtien, Thailand, in 1990 [4].

This paper argues that, notwithstanding the challenges the educational sector in Ghana is facing, the impact of international stakeholders on educational policy making and practice especially at the basic level has been positive in terms of access, financing and infrastructural expansion. The paper which is organized into three sections, will firstly use the Martin Carnoy's analytical framework to explain the rationale behind the educational reforms Ghana pursued under the periods of consideration. Secondly, educational financing under the period of consideration will be discussed. Finally, the paper will discuss the impact in terms of access to "quality "education and infrastructural expansion the international stakeholders support had on basic education.

\section{Analytical Framework}

In order to better understand and appreciate why external educational policies and ideas are selected and retained in particular places, "we need to look more closely at contextual contingencies of a different nature, especially at those of a political and institutional nature" [5]. It is in this regard that, the Martin Carnoy's framework will be used in explaining the educational policies pursued in Ghana under the periods of consideration. This framework explains the impact globalization has on the development and implementation of policies. The framework which was developed based on observation of international educational reform movements in the 1990s.

The main tenets of this framework is that, globalization influences educational policies making at the various levels of the sector with three main rationales. The national educational reforms or policy making will receive much support from the international donor community if such policies are competitiveness, finance and equity based. By competitive based it means that, countries adopt certain educational policies to strive for quality not only because they want their educational system to be competitive but also produce competitive human capital to drive their developmental needs. This thinking is directly linked with the human capital theory which views investment in education as the surest way of improving economic viability of individuals and states at large.

This paradigm which has shaped the economy of most developed countries is supported by both bilateral and multilateral donors. Ghana's educational reforms through the structural adjustment policies adopted in the 1980s was more of competition driven and as such had much support from the international community. According to this framework, a competition driven policy reforms has the following features embedded in them: decentralization, centralization of standards and management of educational resources, teacher recruitment and training school choice as well as privatization of education. These features have been prominent in the educational sector of Ghana after the structural adjustment programmes in the 1980s.
The second tenet of the Carnoy's framework which is closely related to the competition driven policy reforms /making discussed above is finance. Educational policies development which are finance driven are mainly championed by international financial institutions. Though the ultimate objective of such reforms is to improve labour productivity, it does so by ensuring that parents contribute to the cost of educating their children. This is a more prominent impact of globalization on the educational sector in most developing countries. There are three main types of reforms promoted under the finance driven motive of policy making. These are a shift in public funding from higher to lower levels of education, privatization of secondary and higher education as well as reducing cost per student at all levels. Educational reforms have been largely influenced by the finance driven thinking. Ghana called on the International Monetary Fund (IMF) in the 1980s as a result of financial difficulties it faced in those times, there by adopting "global" finance driven policy in the educational sector.

The final reason according to this framework to which policy makers assign to the adoption of certain educational policies is equity. The aim is to use education as means for social mobility and social justice in order to save certain groups from the negative impact of globalization. As a result, the focus of equity driven educational policies is on bringing education to the disadvantaged in society. This according to the framework is done in many ways, through introducing educational policies that will bring quality education to the lowest-income groups, and certain group of the population such as women, rural people and special needs students.

Though many reasons are assigned to the adoption and retaining of certain educational policies at the various levels, from the above it is clear that most of them have been influenced by financial motives. Though all the motives for adopting educational reforms are plausible and can be considered independent, Ghana's educational policy making has been directly or indirectly an embedded one. This suggests that, most reforms in Ghana covertly have the competition and equity motives implicitly or explicitly embedded in the educational policies which are mostly finance driven especially from the 1980s.

\section{Basic Education Funding in Ghana}

As was the case at the international level, Ghana educational policies in the 1960s and 1970s were more geared towards higher education. This was because higher education was viewed at the time to be the only means through which the skilled manpower needed to drive the developmental agenda of nations could be produced [4]. The situation however changed as much attention was given to basic education in the 1980s. This was because basic education was viewed at the international level as the most effective way of eradicating poverty especially in developing countries. This section addresses the financial commitment of the donor community towards basic education in Ghana during the period juxtaposing it to the support the educational sector received from government prior to the 1980s where the educational funding was the sole responsibility of the state. 


\subsection{Pre-independence to 1970}

Initiatives and policies to expand basic education are not new to the Ghana educational sector. It goes back to the pre-independence days. The first of such policies was in 1908 when Governor Rodger sought to expand educational opportunities across the country, especially to the northern part of the country. This was as a result of the concentration of formal education in the coastal areas where the Europeans settled. This initiative was given a boost by Sir Gordon Guggisberg when he introduced the Ten-Year Educational Development Plan of 1920 [6,7].

Notwithstanding, the quest for huge state investment in education started with the Free Compulsory Universal Basic Education (fCUBE) programme introduced by Dr. Kwame Nkrumah in his first educational reform in 1951 under limited self-government (in the Accelerated Development Plan for education). This reform introduced a fee-free compulsory basic education policy for all children aged five to sixteen [8]. The aim was to expand access across the country and to narrow the gap between the north and the south and also between urban and rural areas in relation to access of quality education. This shows that, universal primary education wasn't a new policy to the Ghanaian education sector prior to the international endorsement.

The Universal primary education policy became the Education Act of 1961 (Act 87) when Ghana attained independence. This education policy was to be the driver of the broader desire of modernizing Ghana through industrialization. The reforms under Nkrumah increased the expansion of educational access across the country as primary and middle school enrolments increased by $211.9 \%$ and $141.8 \%$ respectively [9]. However, inadequate funding resulting from the economic downward of the mid 1960s, hampered the realization of the dream of providing fee free basic education to every Ghanaian child. And by the end of Nkrumah's administration in 1966, the quality of education remained poor for many [10]. The period after the overthrow of the first president of Ghana until the early 1980s when Ghana accepted the economic reforms imposed by the Breton Woods Institutions represent what scholars have term the “dark ages” in Ghana's educational history. The political and economic instability led to severe deterioration in education delivery. The 1967 and 1974 education reforms by the National Liberation Council and the Acheampong administrations respectively which sought to improve standards and expand access, failed because of inadequate funding and political instability [6,7,10]. Government's commitment to financing the educational sector declined sharply from $6.4 \%$ to $1.4 \%$ of GDP between 1976 to1983. This resulted in the decline of standards and quality in education. It is argued that by early 1980s, the education system in Ghana had reached crisis level; severely constrained by administrative, performance and resource problems [6,7].

A lot of challenges characterised the educational sector during this period. There was lack of trained teachers, teaching and learning materials (books and teaching aids), and inadequate infrastructure coupled with poor pay for teachers. As a result there were high drop-out rates, low enrolment rates as well as poor management and administration. The main problem of the educational system at the time was general lack of financing. This was generally due to the collective impact of repeated coups, the economic crisis and long strikes by both teachers and students culminating to a fall in public spending on education and consequently quality of education dwindled.

This inadequate investment in the sector resulted not only in the deterioration of the educational infrastructure and shortage of teaching and learning materials, but also made the education sector unattractive to its key stakeholders which led to the exodus of trained teachers to Nigeria. It is estimated that about $50 \%$ of trained teachers had left the country by 1983 [11,12]. Untrained teachers became the option as they were employed by the government in an attempt to prevent the complete disintegration and collapse of the education system [13]. This good intended objective of maintaining the educational system, was however, attained at the expense of quality of education. According to Ahadzie [11], by 1983, the quality of education in Ghana had reached crisis levels and it became necessary for a serious attempt to be made to salvage the situation.

It must be noted that, during this period, (pre independence to 1986) of Ghana's education development, the main source of funding was from government. There was no or limited involvement of external stakeholder and resources.

\subsection{Financing Education from 1980 to 2000}

The introduction of the much needed education reform programme in 1987, which was part of the economic recovery and the structural adjustment programme of the Breton Woods Institutions, brought a paradigm shift to education financing in Ghana. The main objectives of the reform programme was to increase access to basic education, make education more cost effective and improve the quality of education by making it more responsive to the needs and conditions of the country. This reform perhaps is the most comprehensive of all the education reforms Ghana has ever introduced.

At the basic education level, a non-selective basic education across the primary and junior secondary stages was introduced. It aimed at providing children with literacy skills in their own language and in English as well as create a positive attitude to hard work towards national development. Pupils at the basic education level after completing school were expected to become productive skilled workers. This was in line with government's efforts in providing jobs for the teeming youth in an attempt to revive the economy and bring about development after many years of economic challenges. This is exactly what the framework used in this paper espoused. The government of the day concentrated resources on basic education, and technical and vocational education [6]. It must however be noted that this idea was pushed by the donor community. The reform received tremendous support from donors and a lot of external resources were harnessed to support the implementation of the reform.

Evaluation reports on the implementation of the reform programme suggested that, the basic education sector received considerable donor support in a variety of forms, including loans, grants, credits and technical assistance $[7,12,14]$. The World Bank was the leading institution that 
helped in getting support for the reform implementation from other donors to provide Ghana's education sector with two sector budgetary support, thus the Education Sector Adjustment Credit (EdSAC) I (1986-91) and EdSAC II (1990-94). The EdSAC I and II were all part of the structural adjustment policies the government of Ghana agreed to. With support and coordination from the IMF and the World Bank, the EdSAC I was co-financed by several donors including UK's Department for International Development (DFID), UNESCO United Nations Educational, Scientific and Cultural Organization (UNICEF), African Development Bank (AfDB), Norway, Switzerland, German Technical Cooperation (GTZ) and United States Agency for Development (USAID) in 1990. This huge donor support was largely because the EdSAC, received technical assistance from the World Bank and the Bank assumed responsibility for the management of all external projects [9]. The overall donor support Ghana received according to Thompson and Casely-Hayford [7] for the 1986-2002 periods was US\$588.3 million with the World Bank disbursing US\$271 million, while other donors gave US\$317.3 million, between 1987 and 2002 in support of the country's educational reforms.

\subsection{The Impact of the Donor support to Basic Education in Ghana}

The educational reform did not only succeed in channeling a lot of local resources into basic education but also it increased the donor community support to basic education. There was massive expansion in the infrastructure at basic school level and an increase in enrolment. The roles played by different stakeholders in education impacted differently and significantly to education policy making and practice. This section discusses the impact of the donor support basic education in Ghana received during the implementation of the structural adjustment reforms in terms of access and provision of quality/infrastructure education.

\subsubsection{Impact on Infrastructure/Quality of Education}

The impact of the massive donor support the country received in the education sector is reflected in many ways. There was massive improvement in infrastructure, increase in number of teachers and text books available to children. The donor resources received were mainly devoted to school infrastructure due to the huge infrastructural deficit that existed before the adoption of the educational reform. The World Bank (2010) opined in 1988, a year after the launch of the 1987 education reform programme in Ghana that, few (less than half) of basic schools could use all their classrooms when it was raining. However, since 2003, over two thirds of these buildings can be used under any weather condition thanks to the support of the donor community.

For instance, the World Bank provided finance for the construction of more than 8,000 classroom blocks and has procured over 35 million textbooks for basic schools in the last 19 years. This changed the educational landscape as the percentage of primary schools with at least one English textbook per pupil rose from 21\% in 1988 to more than $72 \%$ in 2007 . It must also be noted that, during the same period, Mathematics books per student in Junior Secondary Schools improved (World Bank 2010). With the World Bank providing funding of US\$78 million to the Education Sector Support Programme and the relevant components of the four Poverty Reduction Support Credits, Ghana was able to increase resources to 53 deprived districts, removed mandatory school fees and introduced capitation grants for all pupils in public basic schools throughout the country. Through its budgetary support, the DFID also assisted the government to increase its support to the education sector to $10 \%$ of Government of Ghana expenditure. Other donors such as the Netherlands and World Food Programmes also supported the Ghana School Feeding Programme which seeks to reduce hunger and malnutrition among children and therefore improve access and quality of education in Ghana $[9,15]$.

\subsubsection{Impact on Access to Education}

The 1992 Constitution of Ghana included the Education Act of 1961's idea of providing fee free education for all Ghanaian children. Article 38(2) of the 1992 Constitution indicates that, the Government shall, within two years of parliament first meeting after coming into force of this Constitution draw up a programme for implementation within the following ten years, for the provision of free, compulsory and universal basic education.

Nonetheless, the coming into force of this provision only started in 1996 when the Free Compulsory Universal Basic Education (FCUBE) was launched. It had the objective of providing opportunity for every school going child to receive quality basic education. Emphasis was put on enhancing quality, efficiency in management and expanding access by empowering all partners to participate in the provision of education to all children. This meant that, the provision of access to quality education after the introduction of the educational reforms was not only the responsibility of the government but parents as well. This is what the framework used in this paper indicated, thus most policies are made as a result of financial reasons-cost sharing in the case of Ghana.

The 1996 FCUBE introduced by the government which still maintained the ideals of the educational reforms was seen as a strategic plan that aimed at continuing the implementation of the 1987 reform to ensure quality and access. It had the objective of addressing inequality in access to education especially among girls and those in disadvantaged areas; ensuring efficiency by reducing repetition and dropout rates; improve quality; and make education more relevant to the demands of a modern economy [9]. This human capital idea of investing in education to increase economic productivity and development was also captured by the competitive aspect of the Carnoy's framework of educational policy making and practice. That is, most educational reforms are engineered to provide the needed manpower to drive the developmental agenda of countries especially developing ones.

The reform achieved its goals however small it was as the number of primary school and Junior Secondary school pupils increased by $60 \%$ and $66 \%$ respectively between 1987 and 2006. The number of pupils enrolled in 
primary increased from 1.7 million to 3.1 million within the same period. However, the Gross Enrolment Ratio (GER), showed little growth during most parts of the reform following some initial improvements; after an increased from $74.5 \%$ in 1987 to $79.3 \%$ in 1990 , it declined and after 10 years of implementation, the GER fell to $72.5 \%$ - lower than it was at the time the reforms started. The decline in the GER in 1990 coincided with increases in book fees as a result of World Bank loan conditionality and this, coupled with subsequent increases in fees, dampened the expansion of the access aspect of the reform [9]. This might be because; cost sharing which was part of the conditionalities from the multilateral organizations was new to Ghanaians and also the economic hardship they faced during the period.

Following the Education for All (EFA) Conference held in Senegal, more efforts were made by the donor community to make basic education in Ghana more responsive to the needs of the state. Major donors at this time included the World Bank, USAID and DFID but there were other donors entering the education sector. For instance the USAID initiated a US\$35 million Primary Education Project (PREP) spanning 1990 to 1995, while the World Bank implemented the Primary School Development Project (PSD) (1993-1998). In addition, the Bank funded the Literacy and Functional Skills Project (1991-1995) and National Functional Literacy Project (1992-1998). Donor funding was mostly in project mode.

The support received from the donor community led to significant progress in access expansion and gender equity. Ghana is commended for making tremendous strides towards achieving the Millennium Development Goal 2; universal access to basic education and gender equality at basic level. There have been increases in both Gross Enrolment Rates (GER) and Net Enrolment Rates (NER) over the past two decades especially at basic education level. There have been great improvement in the gender parity index in primary and Junior High School (JHS) with primary gender parity close to one however, it is less at JHS. Primary NER increased from 59\% to $83.6 \%$ between 2001/02 and 2009/10 [16].

It also reflected in Junior High School (JHS) enrolment as well; the NER also increased from $30 \%$ to $47.5 \%$ over the same period. Gender parity index improved from 0.90 to 0.96 for primary and 0.84 to 0.92 for JHS between 2001/02 and 2009/10. However, there are still regional, poverty and rural-urban variations in enrolment and gender parity index. The three Northern regions have the lowest NER in basic and second cycle education. Rural areas also tend to have lower enrolment and wider gender disparity than urban areas and the poor have less girls in school compared to the rich $[16,17]$.

From the above, there is no doubt as to the role of different stakeholders-international stakeholders can have on education. The increase of donor support has improved access to quality education. Notwithstanding the conditionalities attached to the support the country received from the donor community, the impacted has been a positive one. Comparing the educational standards prior to and after the adoption of the structural adjustment policies leaves no doubt in the minds of many that, the educational sector in general has seen tremendous improvement.

\section{Conclusion, Implications and Contributions of the Study}

The educational sector has received much investment by donors and government of Ghana. However, the sector is still faced with monumental challenges. Notwithstanding the numerous challenges the educational sector in Ghana is facing, the involvement of both bilateral and multilateral donors in the policy making process and practice have been positive. There have been more access opportunities created for the citizens who wouldn't have otherwise had the opportunity to taste education. This is because access to education prior to the involvement of the donor partners was limited and was more favourable to the rich and elite in society. The involvement of the donor community has brought about improvement in education infrastructure, and quality inputs such as teachers, textbooks, furniture just to mention a few. It has also helped improve the policy environment for instance the education planning and its annual assessment. Notwithstanding the gains made in the sector with the involvement of the donor community, poverty has not been eradicated; and the provision of access to quality and gender equity based education are some of challenges the sector is still facing.

Though access to education has been generally impressive and improved, there is a huge gap in making it more "quality". Most often, policy makers are preoccupied with policies that create more access than the quality aspect of same. If education can achieve its aim of producing the needed skilled manpower to drive the developmental agenda of the country, serious attention must also be given to the quality aspect of policies as well since they both go in hand in achieving the goal. Although donor assistance has contributed tremendously to improvements within the education sector in Ghana, it cannot be relied upon as a source of funding due to its unpredictability. Economic meltdown in a number of the donors' home countries is expected to affect the quantum of aid inflow. The migration of the country to middle income as well as becoming an oil producing country also imply that Ghana will not qualify for substantial donor assistance to support the education sector.

Though there are several reasons as to why education policy makers accept, adopt and retain certain educational policies (economic, social, political and cultural), the Carnoy's framework was used to explain the rationale that has largely influenced the educational policy adoption in Ghana. Policies are made not only because the state want its educational system to be competitive and relevant at the international level, but also to create a system that can aid in the production of the needed human resources to drive its developmental agenda. It was also shown that policies are made to ensure equity and financial responsibility on the part of parents in the education of their children.

There are growing concerns however that, donor resources is accompanied with direct and indirect controls leading to the argument that where there is growth in donor resources, there is also increasingly less control of the development agenda by governments. They argue that, the donor community, particularly the World Bank and the International Monetary Fund have been undermining 
national "sovereignty" by directly or indirectly directing the development agenda of recipient countries [18]. This position is however in contrast to what happened in India. Though the government of India received huge sums of these aid earmarked for basic education, it stood on it grounds to implement its own educational policies and programmes [4].

With increasing and consistent evidence of a negative correlation between aid and development in developing countries, doubt has been cast on the real impact of donor support on the progress of the education sector [19]. The fundamental question about the impact of aid to the development of the education sector in Ghana is yet to be answered. With Ghana discovering oil in commercial quantities and its migration into a 'middle income status', some donors have already drawn their exit plans [20].

Although government's financial support to education has been increasing, donor resources still remains very important. This is because about $90 \%$ of the financial resources available to the sector is spent on salaries and administrations and as such government will still count on aid to fill the financial gap. The questions however are for how long and to what extent will Ghana continue to rely on foreign aid to support its educational agenda? What will be the impact of donors withdrawing or playing less significant role in the education sector which has received immense contributions in terms of financial support from such stakeholders? Has the Ghana education sector now become more effective and efficient to manage its own educational system very well?

\subsection{Implications for Practice}

The contribution of the donor community towards Ghana's education has implications for the different actors in the sector; policy makers, learners and teachers. For the policy makers, it gives them an idea of the importance of smart investment in the sector and the need to draft policies that reflect not only the needs of the nation but also in tune with global standard to ensure our students are competitive globally. The reason being that education contributes to national development in many ways; it contributes to economic development through increased productivity and earnings.

As indicated by International Institute for Applied System Analysis [21], provision of better education leads not only to higher individual income but also it is a necessary (although not always sufficient) precondition for long-term economic growth and development. Educational planning, for this reason, has always been an integral part of the total economic and social planning that a nation undertakes periodically in order to improve the well being and living conditions of its people. National educational systems are, in this regard, not static. They keep changing in an attempt to response to national development plans and will continue to do so, so long as governments continue to search for new ways and initiate policies that will improve the living conditions of their people. This helps policy makers develop policies that can stand the test of time which wouldn't be affected by regime change.

Educational policies, however well-intentioned, and official curricula, however well crafted, cannot succeed without the teacher, whose professional management of the teaching- learning process ensures that education really takes place (Health \& Education Advice Resource Team [22]). This suggest that, every policy revolves round the teacher who are the final implementers of educational policies. Education delivery has improved tremendously comparatively. This helps teachers to deliver quality teaching as a results of improved infrastructure and provision of adequate teaching materials.

For learners, it is the opportunity to be educated being offered. Investment in education translates not only into the delivery of quality education but also giving more children who ordinarily would have been out of the classroom the opportunity to be educated. Having more of your young population in school has implication for your general development as the human capital base improves a requirement for development.

\subsection{Contribution of the Study}

The article is important in many ways. Aside adding to the already existing knowledge on education funding, it also puts into perspective, how our education, especially basic education has received support from international donors. It also showed how and why the shift of focus from the tertiary to basic education by the international donor community.

Again, the study also indicated the rationale behind the initiation and implementation of educational policies which are likely to receive international support. It gives an idea of how education was financed before and after the pre-colonial era and its correlation with "quality" of education outcome

In conclusion, the article puts into perspective, the path Ghana's education has travelled and reasons behind those paths. Again, it informs readers about the impact investment have on education and its outcomes. Additionally, the study shows how significant globalization has impacted on our national educational policies.

\section{References}

[1] UNESCO. (2010). EFA Global Monitoring Report: Reaching the Marginalized. OXFORD.

[2] Held, D, (1991). Political Theory. Stanford University Press.

[3] Arnove, R. F. (2013). Introduction: Reframing Comparative Education: The Dialectic of the Global and the Local. In: Arnove, R. F. (Ed.) Arnove, R. F., C. A. Torres \& S. Franz (Eds) Comparative Education. The Dialectic of the Global and the Local. Fourth Edition. Lanham: Rowman \& Littlefield Publishers.

[4] Colclough, C. and A. De. (2010). The impact of aid on education policy in India. International Journal of Educational Development 30, pp. 497-507.

[5] Verger, A. (2014). Why do policy-makers adopt global education policies? Toward a research framework on the varying role of ideas in educational reform. Current Issues in Comparative Education, 2014.

[6] Acheampong, K., J. Djangmah., A. Oduro, and A. Seidu (2007), Access to Basic Education in Ghana: The Evidence and the Issues, Consortium for Research on Educational Access, Transitions and Equity (CREATE), Ghana.

[7] Casely-Hayford, L., (2008) Gendered Experiences of Teaching in Poor Rural Areas of Ghana. Eds. Fennell, S., and Arnot, M. (Eds). Routledge.

[8] McWilliam H.O.A. \& Kwamena-Poh, M.A. (1975). The Development of Education in Ghana. London: Longman. 
[9] Palmer. R, Casely-Hayford, L, Ayamdoo, C and Thompson, M. N. (2007). Aid and Donor Partnerships' in the Ghana Education Sector: A critical Review of the Literature and Progress. RECOUP Working Paper 22. Research Consortium on Education Outcomes and Poverty (RECOUP): Accra.

[10] Achanso, S. A. (2010). The Impact of Globalisation on Social Policy in Ghana: the case of external donor agencies and basic education [PhD Thesis, University of Lincoln UK].

[11] Ahadzie, W. (2000), "Education Reform: Equalising Opportunities or Marginalising the Poor? In Social Policy,” Journal of the Centre for Social Policy Studies, University of Ghana, Accra 1(2):

[12] World Bank (2004). Books, Buildings, and Learning Outcomes: An Impact Evaluation of World Bank Support to Education in Ghana, Operations Evaluation Department (OED), World Bank, Washington, D.C.

[13] Konadu (1994). Improving the Development of Teachers: The Ghanaian Experience, International Institute for Education Planning, UNESCO, Paris.

[14] Mettle-Nunoo, R. and Hilditch, L. (2000). Donor Participation in the Education Sector in Ghana. Accra: Action Aid-Ghana. www.elimu.org/_docs/oldsite/countries/rptghana.shtml accessed on 3rd November, 2017

[15] King, K. (2010). China's cooperation in education and training with Kenya: A different model? International Journal of Educational Development 30, 488-496.

[16] MoE (2010) Education Strategic Plan 2010 to 2015. Volume 1: Policies, targets and strategies. Accra: Ministry of Education

[17] UNICEF. (2010). An Analysis of Out of School Children in Ghana: Ghana Demographic and Health Surveys (GDHS) 2003 2008. UNICEF: Accra. University Press.

[18] Takyi-Amoako, E (2010). Examining Aid Effectiveness Paradigm through Education Policy Making in an Aid Dependent country.
The international Journal of Education and Psychological Assessment September 2010, Vol. 5(2).

[19] Osei, D. R (2008). Aid and accelerated Development. Which approach for Ghana? Institute of Democratic Governance (IDEG) Policy Research Series No.4; IDEG, Accra.

[20] EU (2011). Making aid work: from aid effectiveness to development efffectivess. A paper delivered at the Ghana Aid Effectiveness Forum's (GAEF) Road to Busan (HLF4) workshop. Accra 26th October 2011.

[21] IIASA (2008). Economic Growth in Developing Countries: Education Proves Key. IIASA Policy Brief No. 03, August 2008.

[22] Health \& Education Advice Resource Team (2015), Pre-service teacher training in Asian countries.

[23] Carnoy, Martin. (1999) Globalization and educational reform: What planners need to know. UNESCO: IIEP. Fundamentals of Educational Planning, 63.

[24] Krishnan, C.B.(2006). Towards intellectual globalization: A theoretical exploration and its implications for research.

[25] Ministry of Education (2001). 2000/2001 Statistical Digest of the Universities and Institute of Professional Studies, Planning Unit, National Commission for Tertiary Education: Accra.

[26] Perran Penrose (1998). "Compelling Expenditure prioritization in Education”, Background paper for MEFMI/DFID Workshop on Good Practices in Public Expenditure Management, June 1998, Cape Town, South Africa.

[27] Republic of Ghana Constitution (1992).

[28] Tilak. B. G. (2002). Building Human Capital in East Asia: What Others Can Learn. The International Bank for Reconstruction and Development/The World Bank: Washington.

[29] World Bank. (2010). Education in Ghana: Improving Equity, Efficiency and Accountability of Education Service Delivery. World Bank: Washington. 